\title{
The fern Stauropteris oldhamia Binney: New data on branch development and adaptive significance of the hypodermal aerenchyma
}

\section{La fougère Stauropteris oldhamia Binney: données nouvelles sur la croissance des branches et signification adaptative de la présence d'un hypoderme aérenchymateux}

\author{
Maryam Farahimanesh ${ }^{\mathrm{a}}$, Philippe Gerrienne ${ }^{\mathrm{a}}$, Jean Galtier ${ }^{\mathrm{b}}$, \\ Cyrille Prestianni ${ }^{\mathrm{c}, *}$ \\ ${ }^{a}$ PPP unit, Geology Department, University of Liège, avenue du 6-Août B.18/P.40, 4000 Liège, Belgium \\ b AMAP, UMR 5120 CNRS, CIRAD, TA A-51/PS2, boulevard de la Lironde, 34398 Montpellier cedex 05, France \\ c Paleontology Department, Royal Belgian Institute of Natural Sciences, rue Vautier 29, 1000 Brussels, Belgium
}

\section{A R T I C L E I N F O}

\section{Article history:}

Received 2 December 2013

Accepted after revision 19 February 2014

Available online 16 April 2014

Handled by William A. DiMichele

\section{Keywords:}

Stauropterid fern

Hypodermal aerenchyma

Permineralizations

Carboniferous

Belgium

\begin{abstract}
A B S T R A C T
Well-preserved specimens of Stauropteris oldhamia are described. The material was collected in the early 1920s from the Lower Westphalian (Early Pennsylvanian) Saurue seam from Belgium. The fossil plants occur as permineralized axes fragments within a coal ball. This study confirms most of the interpretations made by previous researchers. The observation of immature axis however suggests a less regular organization than previously interpreted beyond the three first branching orders. We also highlight the presence of profusely and dichotomously branched aphlebiae, the lack of laminate organs as well as the presence of hypodermal aerenchyma in all plant parts. We interpret these features as part of a very specialized assimilatory apparatus indicating an adaptation to a humid swamp environment.

(c) 2014 Académie des sciences. Published by Elsevier Masson SAS. All rights reserved.
\end{abstract}

\section{R É S U M É}

Nous décrivons ici des spécimens bien préservés de Stauropteris oldhamia. Ils ont été collectés dans les années 1920 dans la veine Saurue du Westphalien inférieur (Pennsylvannien précoce) de Belgique. Les fossiles végétaux sont trouvés perminéralisés dans des coal-balls. Ce travail permet de confirmer la plupart des interprétations faites par d'autres auteurs. Cependant, l'observation d'axes immatures suggère, au-delà des trois premiers ordres de ramifications, une organisation moins régulière qu'habituellement proposée. Nous mettons aussi en évidence la présence d'aphlébies densément dichotomes, l'absence d'organe plan

\footnotetext{
* Corresponding author.

E-mail address: cyrille.prestianni@naturalsciences.be (C. Prestianni).
} 
ainsi que la présence d'un hypoderme aérenchymateux dans toutes les parties de la plante. Nous interprétons ces caractéristiques comme faisant partie d'un appareil assimilateur très spécialisé indiquant une adaptation à un environnement marécageux humide.

@ 2014 Académie des sciences. Publié par Elsevier Masson SAS. Tous droits réservés.

\section{Introduction}

The Stauropteridales are a group of Palaeozoic (Late Devonian-Carboniferous) ferns that include small herbaceous plants with a four-lobed xylem strand and a quadriseriate (branches borne alternately in pairs) or biseriate (branches borne in two rows) branching; all lack planated appendicular organs. The order is currently represented by the genera Stauropteris Binney (1872), Gillespiea Erwin and Rothwell (1989), Rowleya Long (1966) and putatively Multifurcatus Wang (2003). Stauropteris was formerly classified within the coenopterid ferns (Andrews and Boureau, 1970; Eggert, 1964). Subsequent authors however treated the Stauropteridales as a distinct group demonstrating an early stage in the evolution of the frond (e.g., Taylor et al., 2009). This was strongly supported by phylogenetic analyses (Corvez, 2012; Rothwell, 1999; Rothwell and Stockey, 2008).

The genus Stauropteris Binney, 1872 is characterized by a three-dimensional branching pattern, a slightly asymmetric cruciate protostele and the presence of vascularized aphlebiae that subtend branches (Cichan and Taylor, 1982). What kind of organ the whole branch system of Stauropteris represents (stem, frond?) is still unknown. The genus currently includes four species: the homosporous S. oldhamia Binney (1872) is the type-species; it shows a quadriseriate branching pattern; S. burntslandica (Bertand, 1909) and S. berwickensis (Long, 1966) have also a quadriseriate branching pattern but are heterosporous. The fourth species, S. biseriata (Cichan and Taylor, 1982), exhibits a biseriate branching pattern; its reproductive biology is unknown. The inclusion of the species americana in the genus (Darrah, 1941) has been questioned (Cichan and Taylor, 1982) because the four-lobed stele was not documented.

Here we describe well-preserved permineralised specimens of Stauropteris oldhamia, from a Lower Westphalian (Lower Pennsylvanian) locality of Belgium. The specimens allow for a better understanding of the plant organization and anatomy. New information is also provided on early ontogenetic stages and the development of branches $(N+1$ and $N+2$ axes).

\section{Material and methods}

This study is based on a single coal ball collected by Pr. X. Stainier and later reported by Pr. S. Leclercq (Leclercq, 1935; Stainier, 1924). It was collected from the Saurue seam in the Violette colliery, a lateral equivalent of the well-known Bouxharmont seam of the Werister colliery (Holmes and Fairon-Demaret, 1984; Leclercq, 1935). Both collieries are situated close to Liège, Belgium. The Saurue seam (Violette), synonymous with the Bouxharmont seam
(Werister) and with the Grande Veine d'Oupeye seam (Cheratte) has been attributed to the Lower Westphalian A/Langsettian stage (Lower Pennsylvanian) based on the occurrence of the ammonoid Gastrioceras listeri Sowerby (Chaudoir et al., 1952; Lambrecht et al., 1956; Lhoest et al., 1960).

The coal ball is numbered ULg-1007 and housed in the paleobotany collections of the University of Liège. It contains a dense mass of about 10 specimens of Stauropteris oldhamia. This coal ball was $13 \mathrm{~cm}$ long and has been cut into eight slices. A total number of 1080 cellulose acetate peel sections have been prepared by S. Leclercq using the original liquid peel technique (Walton, 1928) as well as the rapid peel technique (Joy et al., 1956).

The following description refers to the branching patterns with special focus on the apical parts of one selected specimen. This specimen was selected as it is the only one showing an immature development stage. More than 600 peel sections were selected for detailed observation.

The attribution of the specimen to the species S. oldhamia is supported by the occurrence of a quadriseriate branching pattern, by the presence of central parenchyma separating the four primary xylem lobes in $\mathrm{N}$ axes (see below for branch-order terminology), of very divided aphlebiae and of an aerenchymatous hypodermis, all features formerly recognized by Bertrand (1909) and Chaphekar (1962).

\section{Results}

\subsection{Branching and xylem anatomy}

Six axis orders are present among the studied material. It is impossible to reliably assess whether the most proximal and largest axis is the main stem or not. Considering this, we choose to name $N$ the most proximal observed axis order, and $N+1, N+2$, etc. the subsequent axis orders. In transverse section, all the axes appear round to oval in outline. Lower-order axes include a four-lobed xylem strand, with phloem located between the xylem arms. Two planes of symmetry can be distinguished (Fig. 1A). The main plane of symmetry, referred to as the primary plane of symmetry (PPS, Fig. 1A and D) passes through the two main phloem groups. The secondary plane of symmetry (SPS) is perpendicular to the first; it determines the direction of departure of paired $N+1$ axes, which are given off alternately.

The diameter of the basalmost axes ( $\mathrm{N}$-order) ranges from 3 to $5 \mathrm{~mm}$ along both planes of symmetry. They present a stele (about $2 \mathrm{~mm}$ in size, elongated in the PPS) composed of four lobes (Fig. 1A and D). The latter are arranged crosswise and separated by parenchyma in the central area. The xylem includes tracheids with a larger diameter toward the centre of the stele and tracheids with 
a smaller diameter in the outer region. The largest tracheids are interpreted as metaxylem, and the smallest as protoxylem. At least four protoxylem strands are present (arrows, Fig. 1D).

The protoxylem is slightly mesarch and located near the tip of each lobe. Phloem occurs in the bays between xylem lobes. The larger phloem clusters occur along the PPS and are characterized by 4 to 7 (30 to $50 \mu \mathrm{m}$ in diameter) cells (PH, Fig. 1D) which may represent sieve cells. Smaller, and often less well preserved, phloem clusters occur along the SPS and consist of only 2 to 4 (30 to $20 \mu \mathrm{m}$ in diameter) cells. The pattern of emission of traces to the $N+1$ axes conforms to previous descriptions; departing traces of two axes $N+1$ are first visible within the cortex $(\mathrm{t} N+1 \mathrm{~A}$ and B, Fig. 1A). In addition, two small traces (tAP A and B) are also present; they arise very proximally from the traces of $N+1$ axes. They belong to organs traditionally referred to as aphlebiae. These aphlebiae are profusely branched, more or less dichotomous, and nearly $1 \mathrm{~cm}$ long; they have been partially reconstructed in Fig. 3 .

$\mathrm{N}+1$-order axes are significantly smaller than $\mathrm{N}$-order axes. They range from $2.3 \mathrm{~mm}$ to $3.2 \mathrm{~mm}$ in diameter (Fig. 1B and C). They possess a massive tetrarch xylem strand without central parenchyma. Like in N axes, the protoxylem occurs at the tips of the metaxylem lobes and the phloem is located between the xylem arms. The departing traces of two $N+2$ axes are visible within the cortex (Fig. 1B) as well as one aphlebia (AP). Fig. $1 \mathrm{C}$ corresponds to a more distal section of the same $N+1$ axis; it illustrates the coalescent base of one pair of $N+2$ axes as well as the departing traces of the subsequent/second pair of $N+2$ axes, in an alternate arrangement.

The $N+2$ axes measure 1.1 to $1.6 \mathrm{~mm}$ in diameter and are structurally almost the same as to those of the branches of previous orders. However, they present a subtriangular xylem strand but four protoxylem poles are still visible (Fig. 1E). Quadriseriate branching with the occurrence of basal aphlebiae is characteristic of these axes as documented by Bertrand (1909, plate VI, 32-33).

A more important change in xylem shape occurs in more distal branches. $N+3$ axes (Fig. $1 F-G$ ) are much smaller in size, ranging from $1 \times 0.8 \mathrm{~mm}$ to $0.5 \times 0.3 \mathrm{~mm}$, and they possess small triangular xylem strands. However, these small axes produce alternate pairs of $N+4$ axes with a minute trace; this feature was documented by Bertrand (1909, plate VI, 37) and Chaphekar (1962, fig. 4).

Subsequent branching orders $(N+4$ and $N+5$ axes) show a general decrease in overall dimensions, as well as a strong diminution of xylem strand complexity that is progressively reduced to a small number of tracheids (Fig. 1F and G). Branching of these distal axes is dichotomous (iso- or anisotomous). We consider that the smallest axes (about $0.1 \mathrm{~mm}$ in diameter) correspond to the ultimate axis orders (Fig. 1H). Due to their similar size and anatomy, it is impossible to distinguish the distalmost axes from ultimate branches of aphlebiae.

\subsection{Cortical anatomy}

The cortical tissues are very well preserved in all orders of axes. The inner cortex is a parenchymatous ground tissue consisting of cells decreasing in diameter toward the periphery (Fig. 1A, B, E and F). The outer cortex, darker in colour, is composed of smaller and, more sclerotic, thick walled cells. This cortical zonation is observed in axes of orders $\mathrm{N}$ to $N+3$. By contrast, the more distal axes $(N+4$ and $N+5$ ) lack the sclerified zone (Fig. $1 \mathrm{G}-\mathrm{I}$ ).

In all branching orders, the periphery of the cortex is occupied by a narrow zone of spongy parenchyma composed of elongate and thin-walled cells separated by large intercellular spaces; it directly underlies a prominent epidermis (Fig. 1E, J-K). We interpret this tissue as a hypodermal aerenchyma. The development of this tissue causes folding and wrinkles of the axis surface (Fig. 1A, $\mathrm{E}, \mathrm{J})$. The aerenchyma, though reduced to a single cell layer, is also visible in the distalmost axes as confirmed by the longitudinal section, (Fig. 1I). The epidermal cells are square or rectangular in transverse section, measuring about $20 \times 20 \mu \mathrm{m}$ (Fig. 1E, H-K). Such epidermal cells are present even in the smallest axes. The stomata, similar to those illustrated by Bertrand (1909), have been rarely observed and only in ultimate axis order and aphlebiae.

\subsection{Growth pattern and apical region}

We were able to follow and reconstruct an $N+1$ axis from its departure from an $\mathrm{N}$ axis to its tip (Figs. 2 and 3 ). It measures slightly more than $3 \mathrm{~cm}$ long and bears alternately two successive pairs of $n+2$ laterals with aphlebiae (Fig. 2). Proximally, this axis measures about $1 \mathrm{~mm}$ in diameter. The first branching occurs at about three centimetres from the $\mathrm{N}$ axis. The attachment of one pair of $\mathrm{N}+2$-order axes is illustrated in Fig. 2A, where the section is slightly oblique. The two vascular strands of the $N+2$ axes are visible within the cortex, together with the corresponding pair of aphlebia traces (tAP). The transverse section of the $N+1$ axis becomes circular just after emission (Fig. 2B). Unexpectedly, the backward oriented apical region of the same $N+1$-order axis can be seen on the right (arrow, Fig. 2B) near one branched aphlebia. A series of longitudinal oblique sections of the apical region of the $N+1$ axis can be seen on Fig. 2C-E. These peels demonstrate the connection between the two regions of the curved $N+1$ axis. Vascularization is visible nearly up to the apex. However, the poor preservation prevents any detailed description of the topmost apical region. We notice the presence of an irregular surface at the lateral left side of this backward oriented apex (arrows, Fig. 2D). This may represent poorly preserved primordia of $N+2$ axes to be borne distally. The two (proximal and distal) regions of the vascular strand are first visible side by side ( $\mathrm{vN}+1$, Fig. $2 \mathrm{E})$, and then connected (Fig. 2F). The tracheids are cut more longitudinally indicating that this section is located within the fold of the curved axis. The Fig. 2G illustrates a section situated higher within the fold and a single vascular strand is visible. This figure shows also the common base of a second pair of $N+2$ axes. These downward oriented axes are free in Fig. 2F; they are very small, as expected in immature axes; however they are occurring on the expected side. This is an unconventional position considering that the preceding emission of the first pair of $N+2$ axes occurred on the same side (Fig. 2A). Indeed, the typical quadriseriate branching of 

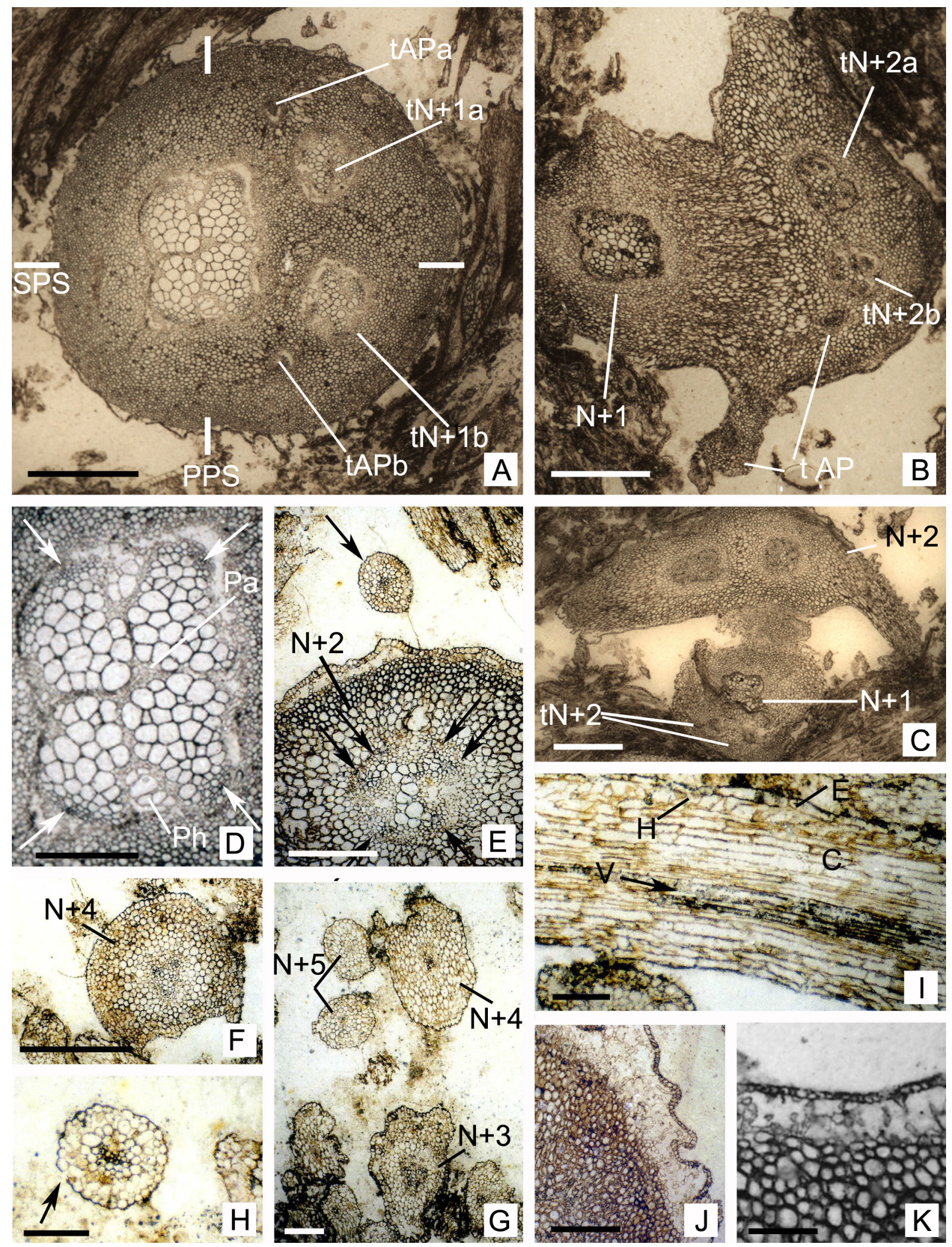
Stauropteris corresponds to the alternate emission of paired axes as illustrated in Fig. 1C. The apparent attachment of the two successive pairs of $N+2$ axes on the same side results from the strong curvature of the top of the $N+1$ axis and of the displacement of the second pair of $N+2$ axes. This is confirmed by the ultimate sections of the series within the recurved left side of cortex. On the Fig. $2 \mathrm{H}$, the two vascular traces of the $N+2$ axes are the only ones present in the cortex; they are cut longitudinally through this curved cortical side. Beyond this level, only smaller and smaller tangential sections of the cortical region are visible and the top of the curve is reached at Fig. 2I. We provide on Fig. 3 the detailed reconstruction of a portion of S. oldhamia where one large $\mathrm{N}$ axis is bearing a pair of $N+1$ axes with their basal aphlebiae. One $N+1$ axis was fully developed (about $3 \mathrm{~cm}$ long) up to its first ramification, i.e. the level of attachment of the first pair of $N+2$ axes with corresponding aphlebiae. Beyond this point, the $N+1$ axis measures only about $0.5 \mathrm{~cm}$ long up to its apical region; it shows the attachment of a second pair of typically immature and displaced $N+2$ axes, then it terminates as an attenuated conical apex. Information about the morphology and eventual branching of the first pair of $N+2$ axes is missing.

\section{Discussion}

\subsection{Morphological organisation of Stauropteris oldhamia}

In this paper, we confirm the distinctive organization of the plant comprised of 6 successive orders of axes, ranging in diameter from $5 \mathrm{~mm}$ to $0.1 \mathrm{~mm}$. The vascular system also decreases in size and complexity from four-lobed xylem strands to very small terete strands in the terminal axes. S. oldhamia is here interpreted as an orthotropic photosynthetic axis bearing determinate lateral branches, the whole exhibiting a bilateral symmetry. Due to the lack of information on the basalmost/proximal region (including roots), it is suggested that the monotypic Stauropteris assemblage contained in the studied coal ball was transported, and represented only the aerial part of the original plant. Actually, we failed finding evidence of attachment of the largest ( $N$-order) axes either to any rooting organ, or to a plagiotropic shoot and we are reduced to speculation about general morphology of the plant. In the last hypothesis, S. oldhamia with its orthotropic photosynthetic branching system, could be compared to the living Psilotum which is sometimes viewed as a "living rhyniophyte" (Bierhorst, 1971), an interpretation challenged by Kaplan (2001) who considered that the simplified nature of the leaf of Psilotum is suggestive of an evolutionary reduction rather than an enation homology. S. oldhamia is however clearly distinct from Psilotum in its repetitive quadriseriate branching system of bilaterally symmetrical axes and in the absence of any small foliar organ. Nevertheless, due to the lack of information concerning a number of characters, the stauropterids appear as a basal clade of ferns, near the "trimerophytes" and the Psilotophytes, in some recent phylogenies (e.g., Rothwell, 1999).

An alternative interpretation is to consider S. oldhamia and the other stauropterids as demonstrating initial stages in the evolution of the leaf (of which the parent stem remains unknown). Emberger (1968) distinguished "Phyllophorées" ferns characterized by fronds, either entirely cauline (Holophyllophorées = stauropterids) or partially cauline (Hétérophyllophorées =e.g. zygopterids and Rhacophyton). In stauropterids, all successive divisions of the frond possessed at least two planes of symmetry (bilaterality) but they were not dorsiventrally symmetrical;

Fig. 1. (Colour online). Sections showing the anatomy of different orders of axes in Stauropteris oldhamia (Saurue seam, Violette colliery, Jupille [Liège]). Specimen ULg-1007. A. Transverse section of a $N$-order axis; the departing traces of two $N+1$ axes are visible within the cortex, with accompanying aphlebia traces (tAPa-b). The two planes of symmetry (PPS and SPS) are indicated. Scale bar $=2 \mathrm{~mm}$. B. Slightly oblique transverse section of a $N+1$-order axis; the departing traces of two $N+2$ axes $(\mathrm{t} N+2 \mathrm{a}-\mathrm{b})$ are visible on the right within the cortex, as well as the trace of one aphlebia (tAP) sectioned twice. Scale bar $=1 \mathrm{~mm}$. C. More distal section of the same axis showing, on the top, the common base of two $N+2$ axes while individualized from the $N+1$ axis. The departing traces of a second pair of $N+2$ axes are visible on the bottom. Scale $=1 \mathrm{~mm}$. D. Detail of $\mathbf{A}$ showing the four-lobed organization of the vascular system with protoxylem strands (arrows) and central parenchyma (Pa) occuring between the metaxylem lobes. Prominent phloem strands (PH) are visible. Scale $=1 \mathrm{~mm}$. E. Partial transverse section of a $N+2$ axis showing the simplified, nearly triangular, vascular bundle with six protoxylem strands (arrows). At the periphery, the aerenchyma and the well-preserved epidermis are present. A small $N+5$ or distalmost axis $(A)$ is associated. Scale $=500 \mu m$. F. Transverse section of a $N+3$ axis showing the triangular xylem strand and small ultimate axes at left. Scale $=1 \mathrm{~mm}$. G. Transverse section through axes of the three distalmost branching orders $(N+3, N+4$ and $N+5)$. Note the reduction in size and simplification of the vascular strand from triangular $(N+3)$ to terete $(N+5)$. Scale $=100 \mu \mathrm{m}$. H. Detail of one distalmost axis $(N+5$ order). Note the occurrence of a stomata (arrow). Scale $=100 \mu \mathrm{m}$. $\mathbf{I}$. Longitudinal section of a similar distalmost axis showing the central vascular strand (v), the cortex (c), hypodermis (h) and epidermis (e). Scale $=200 \mu \mathrm{m}$. J. Transverse section, detail of the periphery of a $N+1$ axis showing the presence of the well-preserved hypodermal aerenchyma and of the epidermis. Scale $=50 \mu \mathrm{m}$. $\mathbf{K}$. Transverse section, detail of the periphery of a $N+3$ axis showing the presence of the well-preserved aerenchyma and of the epidermis. Scale $=50 \mu \mathrm{m}$.

Fig. 1. (Couleur en ligne). Coupes montrant l'anatomie des différents ordres d'axes dans Stauropteris oldhamia (veine de Saurue, charbonnage de la Violette, Jupille [Liège]). Spécimen ULg-1007. A. Section transversale d'un axe d'ordre $N$; les traces vasculaires de deux axes d'ordre $N+1$ sont visibles dans le cortex, ainsi que deux traces d'aphlébies (tAP a-b). Les deux plans de symétrie (PPS et SPS) sont indiqués. Échelle $=2 \mathrm{~mm}$. B. Coupe transversale légèrement oblique d'un axe d'ordre $N+1$; les traces de deux axes $N+2$ sont visibles dans le cortex $(\mathrm{t} N+2 \mathrm{a}-\mathrm{b})$. Échelle $=1 \mathrm{~mm}$. C. Coupe plus distale au sein du même axe montrant, au sommet, la base commune de deux axes $N+2$ en cours d'individualisation de l'axe $N+1$. La trace de départ d'une seconde paire de $N+2$ est visible à la base. Échelle $=1 \mathrm{~mm}$. D. Détail de la partie $\mathbf{A}$ montrant l'organisation des quatre lobes du cylindre vasculaire avec leurs traces vasculaires (flèches) et le parenchyme central $(\mathrm{Pa})$ présent entre les lobes de métaxylème. Un important faisceau de phloème est visible $(\mathrm{PH})$. Échelle = $1 \mathrm{~mm}$. $\mathbf{E}$. Coupe transversale partielle d'un axe $N+2$ montrant le faisceau vasculaire simplifié, presque triangulaire, mais présentant six pôles de protoxylème (flèches). À la périphérie, l'aérenchyme et l'épiderme bien préservé sont présents. Un petit axe $N+5$ (le plus distal) est présent (A). Échelle $=500 \mu m$. F. Coupe transversale d'un axe $N+3$ montrant un xylème triangulaire et de petits axes ultimes. Échelle $=1 \mathrm{~mm}$. G. Coupe transversale au travers d'axes correspondant aux trois ordres de ramifications les plus distaux $(N+3, N+4$ et $N+5)$. Notez la présence d'un stomate (flèche). Échelle $=1 \mathrm{~mm}$. $\mathbf{H}$. Détail d'un axe ultime (ordre $N+5)$. Notez la présence d'un stomate (flèche). Échelle $=100 \mu \mathrm{m}$. I. Coupe longitudinale d'un axe distal similaire montrant le faisceau vasculaire central ( $\mathrm{v}$ ), le cortex (c), l'hypoderme (h) et l'épiderme (e). Échelle $=200 \mu \mathrm{m}$. J. Coupe transversale, détail de la périphérie d'un axe $N+1$ montrant l'hypoderme aérenchymateux bien préservé. Échelle $=50 \mu \mathrm{m}$. K. Coupe transversale, détail de la périphérie d'un axe $N+3$ montrant la présence d'un hypoderme aérenchymateux bien préservé et de l'épiderme. Échelle $=50 \mu \mathrm{m}$. 

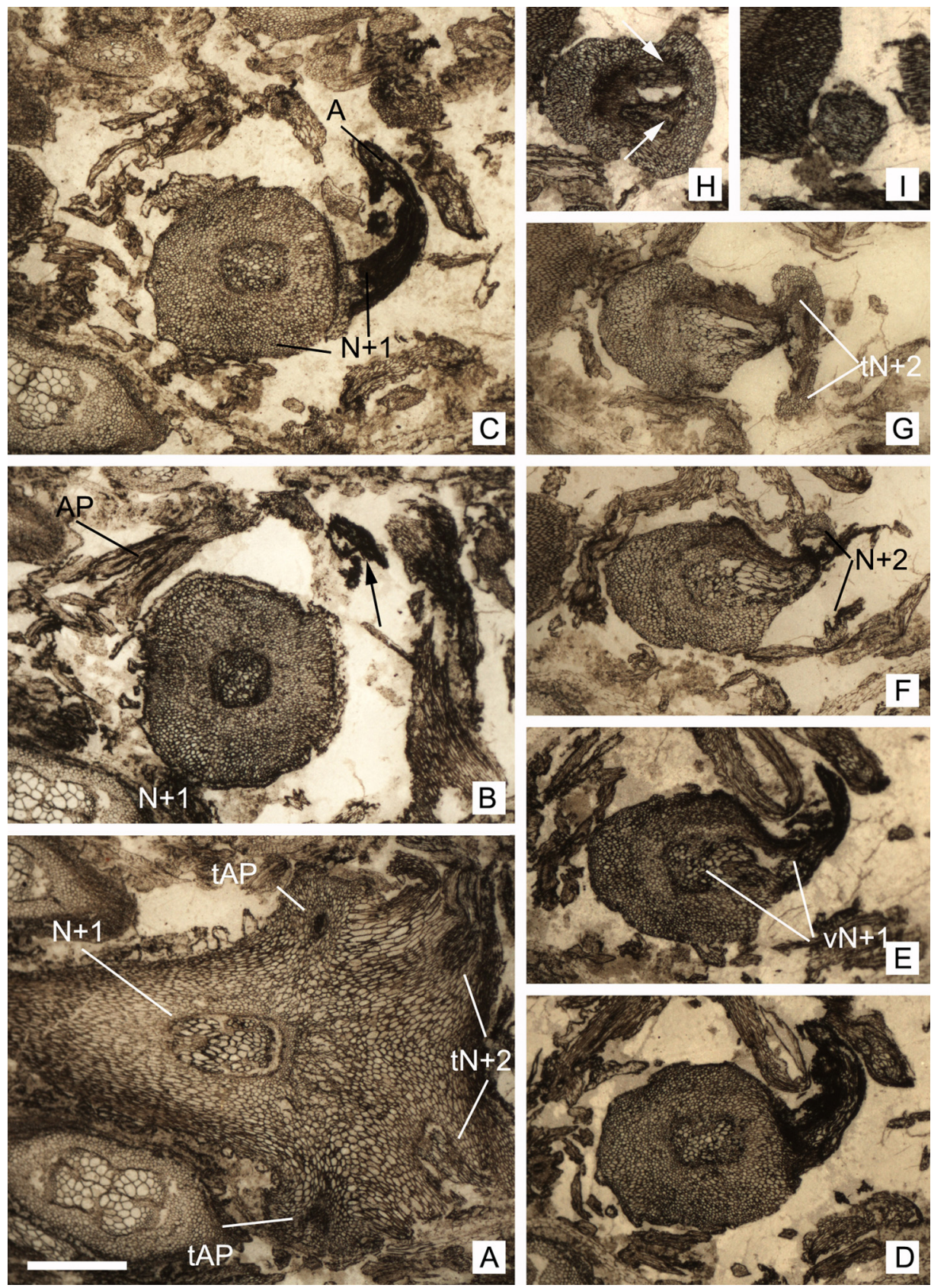

Fig. 2. (Colour online). Serial sections through the apical region of a $N+1$ axis of Stauropteris oldhamia. Specimen ULg-1007. All at the same magnification; scale bar $=1 \mathrm{~mm}$. A. Oblique transverse section of the $N+1$-order axis; the departing traces of two $N+2$ axes are visible on the right within the cortex as well as those of the corresponding aphlebiae (tAP). B. The same $N+1$ axis just after emission showing a more rounded section. The backward oriented apex of the same $N+1$-order axis can be seen at arrow. A part of one branched aphlebia (AP) is also present. C-F. Series of longitudinal oblique sections demonstrating the connection between the proximal and apical regions (A) of the curved $N+1$ axis. The sections of vascularizations from the two levels are first visible side by side (E) and they progressively connect (F). Two immature $N+2$ axes (arrows, F) are oriented downwards. G. Transverse section situated within the fold and showing the recurved vascular strand. The common base of a pair of immature $\mathrm{N}+2$ axes is visible on the right. $\mathbf{H}-\mathbf{I}$. Ultimate sections of the series, situated within the top of the recurved left side of cortex; the pair of vascular traces to $N+2$ axes (arrows, H) are visible.

Fig. 2. (Couleur en ligne). Coupes sériées au sein de la région apicale d'un axe d'ordre $N+1$ de Stauropteris oldhamia. Spécimen ULg-1007. Échelle = $1 \mathrm{~mm}$. A. Coupe transversale oblique de l'axe d'ordre $N+1$; les traces de départ de deux axes $N+2$ sont visibles sur la droite, dans le cortex, ainsi que les aphlébies correspondantes (tAP). B. Le même axe $N+1$ juste après émission montrant une section plus circulaire. L'apex de ce même axe d'ordre $N+1$, mais orienté vers le bas, est indiqué par une flèche. Une partie d'une aphlébie ramifiée est aussi présente (AP). C-F. Série de coupes longitudinales obliques démontrant la connexion entre la partie proximale et la région apicale de l'axe $N+1$ courbé (A). Des coupes au sein des vascularisations de l'axe aux deux niveaux sont visibles côte à côte et se connectent progressivement (F). Deux axes immatures $N+2$ sont orientés vers le bas (flèches, F). G. Coupe transversale située au niveau de la courbure et montrant le faisceau vasculaire recourbé. La base commune de la paire d'axes $N+2$ est visible sur la droite. H-I. Coupes ultimes de la série, situées dans le sommet de la partie gauche de l'axe recourbé ; une paire de traces vasculaires de l'axe $N+2$ (flèches, $\mathrm{H}$ ) est visible. 


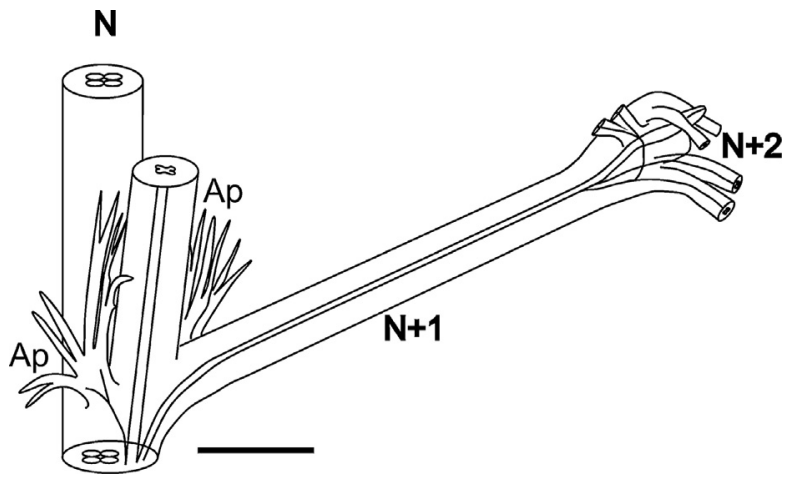

Fig. 3. Restitution of the specimen in Fig. 2, showing the recurved distal axis segment. Scale bar $=500 \mu \mathrm{m}$.

Fig. 3. Reconstitution du spécimen de la Fig. 2 montrant le sommet d'un segment d'axe distal recourbé. Échelle $=500 \mu \mathrm{m}$.

furthermore, as stated above, information on an eventual stem bearing the Stauropteris frond is missing. In contrast, zygopterids showed a clear-cut distinction between the parent stem and helically arranged fronds with a regular phyllotaxis. This is supported by anatomical data: stems had a radially symmetrical protostele while the petiole (= phyllophore) possessed two planes of symmetry perpendicular to each other; therefore this organ was not dorsiventrally symmetrical, in contrast to all the higher order rachides. It is now accepted that zygopterids provided some of the best-documented series of evolutionary processes leading to the megaphyll, even if they did not evolve a fully dorsiventral leaf (Galtier, 2010; Phillips and Galtier, 2005). The zygopterid leaf showed a fundamental step toward the acquisition of the dorsiventrality (cf. Kaplan, 2001) or adaxial/abaxial identity (= "abdaxity" character of Corvez et al., 2012), which is yet absent in the phyllophore but present in the next-order rachises of zygopterids. Abdaxity, as defined from leaf traces with abaxial protoxylem in seed plants but adaxial protoxylem in ferns (Galtier, 2010), allows characterizing the megaphyll of most Euphyllophytes. By analogy with the situation in zygopterids, it is our opinion that the aerial branching system of Stauropteris may represent a leaf precursor in which the proximal $(N$ to $N+3)$ axes show a bilateral symmetry; however, the generalized absence of abdaxity is indicative of a less advanced stage in the evolution of the frond than in zygopterids and even in rhacophytaleans where abdaxity is only absent in the two most proximal orders of axes of the frond.

Due to their anatomical and morphological particularities, the affinities of Stauropteridales have been and remain matter of debate. In earliest discussions, Stauropteris was classified within the zygopterid ferns (Bertrand, 1909) and later included within the Coenopteridales (Andrews and Boureau, 1970; Eggert, 1964). The latter group is now known to be paraphyletic. Stauropteridales are more accurately treated (e.g., Taylor et al., 2009) as a distinct group, near the Rhacophytales and the Zygopteridales, demonstrating a different early stage in the evolution of the frond. This is confirmed by a recent phylogenetic analysis (Corvez,
2012) whilst stauropterids appear as a basal clade near the Psilotophytes in other analyses (e.g., Rothwell, 1999).

\subsection{Ecological adaptation}

Of particular interest is the occurrence, in S. oldhamia, of an aerenchymatous hypodermis and of a prominent epidermis in all branching orders. We confirm the presence of stomata as previously mentioned by Bertrand (1909) and Chaphekar (1962). In the absence of any laminate organ, we interpret the hypodermis as necessary to the assimilatory function, which suggests that photosynthesis was occurring in all orders of axes.

It is certainly significant that the aerenchymatous hypodermis is absent from the older S.burntislandica found in volcanic environments of Pettycur (Bertrand, 1909; Surange, 1952) and of the Roannais (Galtier, 1971). Such a hypodermis has been occasionally mentioned in other representatives of the genus. In S. berwickensis, from both volcanic and fluviatile environments (Scott and Galtier, 1996) the occurrence of this tissue was suggested but not illustrated by Long (1966). Cichan and Taylor (1982) mentioned a narrow hypodermis in the main axis of S. biseriata. In both cases, the hypodermis seems to be restricted to the proximal $N$-order axis only, and its aerenchymatous nature was not mentioned.

The presumably generalized assimilatory function of all the axes of S. oldhamia is a very important feature. It contrasts with the situation in all known earliest ferns where the assimilatory function is restricted to the ultimate branching orders, in the form of either unwebbed cylindrical segments or of small laminated pinnules (Galtier, 2010). This character also contrasts with the occurrence of laminated pinnules in several coeval ferns from Bouxharmont: Ankyropteris, Corynepteris and Psalixochlaena (Holmes and Fairon-Demaret, 1984; Phillips and Galtier, 2005, 2011).

An assimilatory function generalized to all axis orders is considered plesiomorphic to all plant groups (Kenrick and Crane, 1997). The presence of this character in the Carboniferous Stauropteris plant is puzzling. Two contrasting hypotheses can be considered. First, it is a plesiomorphic character that survived among Stauropteridales. Second, it is the result of a character reversion. We consider the second hypothesis as unlikely because the earliest representatives of the Stauropteridales, currently represented by the Devonian genus Gillespiea (Erwin and Rothwell, 1989), were similarly lacking specialized assimilatory organs. Furthermore, the assimilatory hypodermis seems to be more developed in the youngest S. oldhamia than in the earlier stauropterids; this may represent an adaptation to a humid coal swamp environment. There is however no clear evidence suggesting that S. oldhamia lived in semiaquatic environments. Another hypothesis is suggested by the study of isoetalean lycopsids. In a reinterpretation of the parichnos system of Pennsylvanian lepidodendrales, Green (2010) suggested that it could represent an unusual metabolism similar to that of modern Isoetaceae. It consists of a particular photosynthetic pathway related to aquatic CAM photosynthesis (Keeley, 1998). In this model, the parichnos system represents internal gas spaces used as a carbon-concentrating mechanism. The parichnos 
system is thus similar to aerenchyma and used to provide upward $\mathrm{CO}_{2}$ transport and downward $\mathrm{O}_{2}$ transport. Such mechanism of $\mathrm{CO}_{2}$ enrichment is particularly interesting within the context of the high $\mathrm{O}_{2}$, low $\mathrm{CO}_{2}$ late Palaeozoic atmosphere. A similar process could be proposed for Stauropteris. Indeed, the occurrence of aerenchyma in all branches order as well as the lack of stomata is consistent with this hypothesis.

The Stauropteridales appear to be a very specialized group occupying a particular position among earliest fern evolution. They are devoid of any lamina, like the very different, and supposedly leafless, cladoxylaleans. They are also quite distinct anatomically from the rhacophytaleans, zygopterids and other fern groups which exhibit, from the Late Devonian, the slow process of acquisition of laminate pinnules.

\subsection{Reconstruction}

Several reconstructions of S. oldhamia have been published (e.g., Chaphekar, 1962; Eggert, 1964; Mägdefrau, 1967) and reproduced in textbooks. The study of this coal ball containing several branched axes allows confirmation of the overall validity of these reconstructions. All these reconstructions, however, emphasize a very regular organization of the plant. They show organs emitted in opposite pairs giving a repetitive quadriseriate aspect to all branching orders. For example, Chaphekar (1962) and Mägdefrau (1967) illustrated $N+1$ axes bearing at least four successive pairs of $N+2$ axes and, in turn, $N+2$ axes bearing at least four successive pairs of $N+3$ axes at regular intervals. Here we describe the distalmost parts of the plant. They highlight an organization contrasting with previously published reconstructions. Indeed, we notice in the ultimate branching orders (after $N+3$ ) a progressive loss of the four-lobed organization prevailing in other orders. Additionally, we provide the detailed reconstruction of a portion of this plant where one $\mathrm{N}$ axis is bearing immature $N+1$ to $N+2$ axes. The $N+1$ axis was fully developed up to its first ramification. In contrast, the remaining part of this $N+1$ axis, up to its apical region, measures only about $0.5 \mathrm{~cm}$ and includes a second level of ramification. The very short distance between the levels of attachment of the two successive pairs of $N+2$ axes is suggestive of an arrest of growth. This is confirmed by the rapid decrease in diameter of the $N+1$ axis after its second branching level as well as by the conical shape of its apical region. This also suggests, for S. oldhamia, some kind of determinate growth comparable with the development found in the leaves of some modern ferns. This may be considered as an argument to interpret the whole aerial branching system as a primitive fern frond (see discussion above). If there is no doubt that $N+1$ to $N+3$ axes were arranged as paired branches, evidence is missing of a quadriseriate arrangement of all branching orders. In addition, it is probable that the interval between successive branches was quickly decreasing and that the number of the successive paired branches was smaller than 4 or 5 , as suggested in previous reconstructions. Despite the curvature observed in the distal-most region of this $N+1$ axis, it is impossible to assess whether it is resulting from taphonomic processes or corresponding to an origi- nal circination. In spite of the exquisite preservation of the epidermal tissue, the absence of any ramentum, including in the apical region, appears characteristic of this plant.

\section{Conclusions}

This study of S. oldhamia from the Early Pennsylvanian from Belgium confirms most of the observations and interpretations made by Bertrand (1909) and Chaphekar (1962). S. oldhamia, and the Stauropteridales, appear to be very specialized plants occupying a particular position in fern evolution. S. oldhamia is characterized by a quadriseriate organization and a four-lobed protostele. This organization is very regular in the three first branching orders, but is progressively lost in distal parts where small terete appendages are present. The profusely and dichotomously branched aphlebiae constitute an important element of the branching system. The lack of laminate organs is another characteristic aspect of S. oldhamia. The assimilatory function is very likely generalized to all plant parts as implied by the presence of the aerenchyma and stomata. We interpret the latter features as indicating an adaptation to the humid swamp environment.

\section{Acknowledgements}

P. Gerrienne is a FRS-FNRS Senior Research Associate.

\section{References}

Andrews, H.N., Boureau, E., 1970. Classe des Coenopteridopsida. In Boureau, E. (Ed.), Traité de paléobotanique, 4(1). Filicophyta. Masson, Paris, pp. 47-51.

Bertrand, P., 1909. Études sur la Fronde des Zygoptéridées. Danel, Lille, $286 \mathrm{p}$.

Bierhorst, D.W., 1971. Morphology of Vascular Plants. Macmillan, New York, 560 p.

Binney, E.W., 1872. On a specimen of Stauropteris oldhamia. Proc. Lit. Phil. Soc. Manchester 11, 69.

Chaphekar, M., 1962. The Morphology of Stauropteris oldhamia Binney. Palaeobotanist 11, 123-130.

Chaudoir, H., Lambrecht, L., Pastiels, A., Willière, Y., 1952. Étude géologique du Bassin Houiller de Liège - La concession de Espérance, Violette et Wandre. Association pour l'Étude de la Paléontologie et de la Stratigraphie Houillères publication $\mathrm{n}^{0} 15,13 \mathrm{p}$.

Cichan, M.A., Taylor, T.N., 1982. Structurally preserved plants from southeastern Kentucky: Stauropteris biseriata sp. nov. Am. J. Bot. 69, $1491-1496$.

Corvez, A., 2012. L'origine de la mégaphylle chez les Monilophytes. Muséum National d'Histoire Naturelle, Paris, 276 p (unpublished thesis)

Corvez, A., Barriel, V., Dubuisson, J.Y., 2012. Diversity and evolution of the megaphyll in Euphyllophytes: phylogenetic hypotheses and the problem of foliar organ definition. C. R. Palevol. 11, 403-418.

Darrah, W.C., 1941. The Coenopterid ferns in American coal balls. Am. Midland Naturalist 25, 233-269.

Eggert, D.A., 1964. The question of the phylogenetic position of the Coenopteridales. Mem. Torrey Botanical Club 21, 38-57.

Emberger, L., 1968. Les plantes fossiles dans leurs rapports avec les végétaux vivants. Masson, Paris, $758 \mathrm{p}$.

Erwin, D.H., Rothwell, G.W., 1989. Gillespiea randolphensis gen. et sp. nov. (Stauropteridales), from the Upper Devonian of West Virginia. Rev. Can. Bot. 67, 3063-3077.

Galtier, J., 1971. Sur les flores du Carbonifère inférieur d'Esnost et du Roannais. Bull. Soc. Hist. Nat. Autun 57, 24-28.

Galtier, J., 2010. The origins and early evolution of the megaphyllous leaf. Int. J. Plant Sci. 171, 641-661.

Green, W.A., 2010. The function of the aerenchyma in arborescent lycopsids: evidence of an unfamiliar metabolic strategy. Proc. R. Soc. B 267, 2257-2267. 
Holmes, J.C., Fairon-Demaret, M., 1984. A new look at the flora of the Bouxharmont coal balls from Belgium. Ann. Soc. Geol. Belgique 107, 73-87.

Joy, K.W., Willis, A.J., Lacey, W.S., 1956. A rapid cellulose peel technique in palaeobotany. Ann. Bot. 20, 635-637.

Kaplan, D.R., 2001. The science of plant morphology: definition, history and role in modern biology. Am. J. Bot. 88, 1711-1741.

Keeley, J.E., 1998. CAM photosynthesis in submerged aquatic plants. Botanical Rev. 64, 121-175.

Kenrick, P., Crane, P.R., 1997. The Origin and Early Diversification of Lands Plants: A Cladistic Study. Smithsonian Institution Press, Washington.

Lambrecht, L., Charlier, P., Demanet, F., Pastiels, A., Willière, Y., 1956. Étude géologique du Bassin Houiller de Liège-Le Westphalien inférieur et le Namurien de la région Cheratte-Argenteau. Association pour l'Étude de la Paléontologie et de la Stratigraphie Houillères publication $n^{\circ} 25$, $98 \mathrm{p}$.

Leclercq, S., 1935. Coal-balls de la couche Saurue, synonyme de Bouxharmont. Bull. Soc. R. Sci. Liege 4-5, 1-6.

Lhoest, A., Pastiels, A., Willière, Y., 1960. Les zones de Beyne et d'Oupeye à Souverain-Wandre (Nord de Liège). Centre National de Géologie Houillère Document $n^{\circ} 2,90 \mathrm{p}$.

Long, A.G., 1966. Some Lower Carboniferous fructification from Berwickshire, together with a theoretical account of the evolution of ovules, cupules and carpels. Trans. R. Soc. Edinb. 66 (14), 345-375.

Mägdefrau, K., 1967. Niedere Pflanzen. In: Strasburger, Lehrbuch der Botanik. 29. Aufl, Stuttgart, pp. 379-534.
Phillips, T.L., Galtier, J., 2005. Evolutionary and ecological perspectives of Late Paleozoic ferns Part I. Zygopteridales. Rev. Palaeobot. Palynol. 135, 165-203.

Phillips, T.L., Galtier, J., 2011. Evolutionary and ecological perspectives of Late Paleozoic ferns: Part II. The genus Ankyropteris and the Tedeleaceae. Rev. Palaeobot. Palynol. 164, 1-29.

Rothwell, G.W., 1999. Fossils and ferns in the resolution of land plant phylogeny. Bot. Rev. 65, 188-218.

Rothwell, G.W., Stockey, R.A., 2008. Phylogeny and evolution of ferns: a paleontological perpective. In: Ranker, T.A., Haufler, C.H. (Eds.), Biology and Evolution of Ferns and Lycophytes. Cambridge University Press, Cambridge, $480 \mathrm{p}$.

Scott, A.C., Galtier, J., 1996. A review of the problems in the stratigraphical, palaeoecological and palaeogeographical interpretation of Lower Carboniferous (Dinantian) floras from western Europe. Rev. Palaeobot. Palynol. 90, 141-153.

Stainier, X., 1924. Nodules dolomitiques avec végétaux à structure conserve du Houiller belge. Bull. Soc. Belge Geol. Paleontol. Hydrogeol. 34,26

Surange, K.R., 1952. The morphology of Stauropteris burntislandica P. Bertrand and its megasporangium Bensonites fusiformis R. Scott. Phil. Trans. R. Soc. London B237, 73-91.

Taylor, T.N., Taylor, E.L., Krings, M., 2009. Paleobotany: The Biology and Evolution of Fossil plants. Academic Press, Amsterdam, 2130 p.

Walton, J., 1928. A method for preparing fossil plants. Nature 122, 571.

Wang, Y., 2003. A new plant from the Earliest Carboniferous of Jiangsu, China. Alcheringa Australas J Palaeontol 27, 51-61. 